\title{
GENETIC PURITY CERTIFICATE IN SEEDS OF HYBRID MAIZE USING MOLECULAR MARKERS ${ }^{1}$
}

KALINKACARLAPADOVANI DE CARVALHO SALGADO², MARIADAS GRAÇAS GUIMARÃES CARVALHO VIEIRA ${ }^{3}$, ÉDILA VILELADE RESENDE VONPINHO ${ }^{3}$, CLÁUDIA TEIXEIRA GUIMARÃES ${ }^{4}$, RENZO GARCIA VONPINHO ${ }^{3}$, LOURENÇO VIANADE SOUSA ${ }^{5}$

\begin{abstract}
One of the main features that confer high quality to the seed is its genetic purity, in which one of the major causes of contamination is the self-pollination of the female parent. Up to date, there is no accurate and fast methods for detecting such contamination. Thus, this work was carried out to certify the genetic purity in seeds of hybrid maize using different biochemical and DNA-based markers. Two single-cross hybrids and their parental lines derived from the maize breeding program at UFLA were evaluated by isoenzymatic pattern of alcohol dehydrogenase $(\mathrm{ADH})$, esterase (EST), acid phosphatase (ACP), glutamate-oxaloacetate transaminase (GOT), malate dehydrogenase (MDH), isocitrate dehydrogenase (IDH), phosphoglucomutase (PGM), 6phosphoglucomate dehydrogenase (PGDH), catalase (CAT) and ß-glucosidade (ßGLU) and by microsatellites markers. The enzymatic systems that were able to distinguish the hybrids from their parental line were the catalase, the isocitrate dehydrogenase and the esterase. The esterase showed a Mendelian segregation pattern for UFLA $8 / 3$ hybrid, that enables a safer genetic purity certificate. Microsatellites were able to differentiate the hybrid lines and the respective parental lines. Moreover, this technique was fast, precise and without environment effects. For microsatellites, the amplification pattern was identical when young leaves or seeds were used as DNA source. The possibility of using seeds as DNA source would accelerate and facilitate the role process of the genetic purity analysis.
\end{abstract}

Index terms: Zea mays, microsatellites markers, isoenzymatic markers.

\section{CERTIFICAÇÃO DA PUREZA GENÉTICAEM SEMENTES DE MILHO HÍBRIDO POR MEIO DEMARCADORES MOLECULARES}

\begin{abstract}
RESUMO - Um dos principais atributos que conferem à semente uma alta qualidade é sua pureza genética, sendo a principal causa de contaminação em sementes de milho híbrido, a ocorrência de autofecundação do parental feminino. No entanto, ainda não existem metodologias seguras e rápidas para detectar tais contaminações. Desta forma, o presente trabalho foi desenvolvido objetivando certificar a pureza genética em sementes de milho híbrido por meio de diferentes técnicas de marcadores bioquímicos e de DNA. Sementes de dois híbridos e de suas respectivas linhagens, provenientes do programa de melhoramento da Universidade Federal de Lavras foram avaliadas por padrões eletroforéticos das isoenzimas álcool desidrogenase (ADH), esterase (EST), fosfatase ácida (ACP), glutamato-oxalacetato transaminase (GOT), malato desidrogenase (MDH), isocitrato desidrogenase (IDH), 6-fosfoglucamato desidrogenase (PGDH), fosfoglucomutase (PGM), catalase (CAT) e ß-glucosidade (ßGLU) e por marcadores microssatélites. Os sistemas enzimáticos que permitiram separar os híbridos de seus respectivos progenitores foram a catalase, a isocitrato desidrogenase e a esterase, sendo que para a esterase foi observada segregação mendeliana para o híbrido UFLA 8/3, o que torna a certificação da pureza genética mais segura. Os microssatélites
\end{abstract}

\footnotetext{
${ }^{1}$ Submetido em 03/11/2004. Aceito para publicação em 06/06/2005;

${ }^{2}$ Pós graduanda do Depto. de Agricultura - UFLA. C.P.37 - CEP 37200000 - Lavras, MG, kaka@ufla.br;
}

\footnotetext{
${ }^{3}$ Prof. Dr., Depto de Agricultura - UFLA;

${ }^{4} \mathrm{Dr}^{\mathrm{a}}$, Pesquisadora EMBRAPA Milho e Sorgo;

${ }^{5}$ Pós graduando do Depto. de Biologia - UFLA.
} 
além de terem sido eficientes na diferenciação dos híbridos e das linhagens parentais, apresentaramse como uma técnica de análise rápida, precisa e independente do ambiente. Como o padrão de amplificação dos microssatélites não foi influenciado quando se utilizou o DNA extraído de sementes inteiras ou de folhas, torna-se possível a utilização de sementes como fonte de DNA, o que acelera e facilita a execução das análises de pureza genética.

Termos para indexação: Zea mays, marcadores microssatélites, marcadores isoenzimáticos.

\section{INTRODUCTION}

Seed quality influences directly the crop productivity and it can be highlighted as a combination of genetic, physiological and sanitary attributes. The isolation of the seed production fields, the removal of the female parental tassel, the cleanning of the harvest and processing machinary are some of the criteria adopted to maintain the genetic purity of maize hybrid seeds. In the field production of maize hybrid seeds, the main source of genetic contamination is the self-pollination of the female parent due to the incomplete removal of its tassel. This contamination increases the endogamic levels, reducing the genetic and physiological quality of the seeds that consequently decreases the crop productivity. Another great issue related to the self-pollination is the exposure of female lines in the market that is undesirable to all seed companies.

Althorgh the limited factors, such as large areas, environment influence and the labor force, the genetic purity certification in maize has been mostly performed using morphological traits. However, the isoenzymes and DNAbased markers have been proposed as an additional method to certify genetic seed purity, and are also applied in some seed companies. Cooke (1995) showed that the isoenzymatic profile could be used in the genetic purity evaluation of seeds from a great number of plant species, using a single seed from each material. In maize, 20 isoenzymatic loci allowed the distinction of around 75 to $85 \%$ of the commercial US hybrid from their female self-pollinated inbred line (Smith and Register III, 1998). Mauria et al. (2000) reported that Malate dehydrogenase (Mdh), acid phosphatase (Acp), phosphoglucoisomerase (Pgi), 6-phosphogluconate dehydrogenase (Pad) and isocitrate dehydrogenase (Idh) were the most informative isozyme systems for characterisation of the maize inbreds. Orman et al. (1991) showed that the isoenzymatic electrophoretic pattern of acid phosphatase, alcohol dehydrogense, isocitrate dehydrogenase, malate dehydrogense, 6-phosphogluconate dehydrogenase, phosphoglucomutase and phosphohexoisomerase, in addition to morphological traits could be successfully used in maize cultivar identification. Indeed, many isoenzymatic systems are recommended for cultivar identification and genetic purity certification in maize (AOSA, 1991).

The main advantage of DNA markers is the unlimited number of polymorphisms randomly distributed in the genome without environmental effects and without influence of plant physiological development, so that is is an interesting methodology to evaluate the genetic purity in seeds (Lanza et al., 2000). Among the DNA markers, microsatellites or SSRs ("Simple Sequence Repeats") have additional attributes such as codominance and multiallelism that make them one of the best choices for the identification of genetic contamination. Sivolap and Kozhukhova (2004) showed that in the analysis of ten SSR loci, 40 genotypes were unique. For every locus, SSR analysis revealed heterozygotes among simple hybrids, which made it possible to identify the parental forms with a high probability of exclusion of nonparental forms. Additionally, microsatellites are PCR-based, are widely available and the technique is standardized among laboratories (Guimarães and Moreira, 1999).

This study was carried out to evaluate the isoenzymatic and microsatellite markers ability to distinguish single-cross hybrids from their parental lines, in order to apply the techniques in the evaluation of genetic purity in maize hybrid seeds.

\section{MATERIAL AND METHODS}

Genetic materials - Two single-cross hybrids and their respective parental lines derived from the maize breeding program at UFLA (Universidade Federal de Lavras) were used as source for protein and DNA extraction.

Isoenzymatic systems - For the proteins extracted from leaves and coleoptiles, 50 seeds of each material were germinated separately in a growth chamber at $25^{\circ} \mathrm{C}$ with 12 hours of light. The seedlings were then planted in plastic boxes with soil and sand in the same proportion with a $70 \%$ retention capability, for seven days. Each tissue sample (coleoptiles, leaves or seeds) was ground at $4^{\circ} \mathrm{C}$ and the powder was stored 
at $-80^{\circ} \mathrm{C}$. The protein was extracted from $100 \mathrm{mg}$ of powder mixed in $200 \mathrm{~mL}$ of buffer $(0.2 \mathrm{M}$ Tris- $\mathrm{HCl}, \mathrm{pH} 8.0)$ and homogenized for 24 hours at $10^{\circ} \mathrm{C}$. After this, samples were centrifuged at $16.000 \mathrm{~g}$ for 30 minutes at $4^{\circ} \mathrm{C}, 40 \mathrm{~mL}$ seed extraction and $60 \mathrm{~mL}$ coleoptiles and leaves were applied in a gel. The protein profile was resolved in $7.5 \%$ polyacrylamide gel, with a $4.5 \%$ concentrator gel, running at $12 \mathrm{~mA}$ in the concentrator gel and $24 \mathrm{~mA}$ in the separator gel.

The gels were developed for enzymatic systems: dehydrogenase alcohol (ADH), esterase (EST), acid phosphatase (ACP), glutamate-oxalacetate transaminase (GOT), malate dehydrogenase (MDH), isocitrate dehydrogenase (IDH), 6-phosphoglucamate dehydrogenase (PGDH), phosphoglucomutase (PGM), catalase (CAT) and ß-glucosidase (ßGLU), according to Alfenas (1998).

Leaf DNA extraction - The genomic DNA was extracted from leaves of 50 seedling of each hybrid and parental lines. Dried leaf material was ground with liquid nitrogen and combined with $10 \mathrm{~mL}$ of CTAB buffer $(2 \%$ CTAB; $1 \mathrm{M}$ Tris$\mathrm{HCl}, \mathrm{pH} 7.5 ; 0.5 \mathrm{mM}$ EDTA, $\mathrm{pH} 8.0 ; 5 \mathrm{M} \mathrm{NaCl} ; 2 \%$ bmercaptoethanol) and samples were incubated for 90 minutes at $65^{\circ} \mathrm{C}$. After this time, $5 \mathrm{~mL}$ of chloroform-octanol $(24: 1)$ was added and kept under constant shaking for 15 minutes and samples were spun at $735 \mathrm{~g}$. The supernatant was transferred to another tube, to which $6 \mathrm{~mL}$ cold isopropanol was added. Pellets were dissolved in $3 \mathrm{~mL}$ TE pH $8.0(0.1 \mathrm{mM}$ Tris-HCl; $0.1 \mathrm{mM}$ EDTA) and incubated at $37^{\circ} \mathrm{C}$ for 1 hour with $30 \mathrm{~mL}$ of RNAse $\left(10 \mathrm{mg} \cdot \mathrm{mL}^{-1}\right)$. DNA was then precipitated with $95 \%$ ethanol, washed with $70 \%$ ethanol and ressuspended in 500mL TE. DNA samples were quantified in $0,8 \%$ agarose gel treated with ethidium bromide $(0.5 \mathrm{mg} /$ $\mathrm{mL}$ ) and visualized under UV light compared with DNA of known concentration.

Seed DNA extraction - Individual seeds from each genotype were ground with liquid nitrogen and 200mg sample combined with $200 \mathrm{~mL}$ extraction buffer $(100 \mathrm{mM}$ Tris- $\mathrm{HCl}$, pH 8.5; 100mM NaCl; 20mM EDTA pH 8.0; 1\% sarcosyl). Samples were rested for 10 minutes and $600 \mathrm{~mL}$ of phenol was added and mixed for 5 minute. After samples were spun at $16.000 \mathrm{~g}$ for 10 minutes, the top layer was removed and $5 \mathrm{~mL}$ RNAse $\left(10 \mathrm{mg} . \mathrm{mL}^{-1}\right)$ were added. Samples were incubated at $37^{\circ} \mathrm{C}$ for 1 hour. Afterwards, $400 \mathrm{~mL}$ cold isopropanol was added, incubated at $-80^{\circ} \mathrm{C}$ for 30 minutes and centrifuged at $16.000 \mathrm{~g}$ for 10 minutes to pellet the DNA. Pellets were washed in $500 \mathrm{~mL} 70 \%$ ethanol for 5 minutes, dried and rehydrated in $50 \mathrm{~mL}$ water. The DNA was quantified according to the method described above.
Microsatellites markers - Initially, 27 microsatellite primers were evaluated among the maize inbred lines and hybrids using the DNA extracted from the young leaves. The primers were supplied by Research Genetics, Inc. (Huntsville, AL), whose sequences are publicly available at the Maize Genetics and Genome Database (http://www.maizegdb.org/ ssr.php). The PCR reactions consisted of $10 \mathrm{ng}$ DNA, $0.6 \mathrm{mM}$ each primer, $100 \mathrm{mM}$ each dNTP, $10 \mathrm{mM}$ Tris- $\mathrm{HCl}(\mathrm{pH} 8.6)$, $50 \mathrm{mM} \mathrm{KCl}, 2 \mathrm{mM} \mathrm{MgCl}$ and $1 \mathrm{U}$ of the enzyme Taq DNA polymerase, in a final volume of $10 \mathrm{~mL}$. The amplifications were performed in a Perkin Elmer 9600 thermocycler with an initial denaturation step of $94^{\circ} \mathrm{C}$ for 2 minutes, followed by nine cycles of $94^{\circ} \mathrm{C}$ for 20 seconds, $68^{\circ} \mathrm{C}$ for 20 seconds and $72^{\circ} \mathrm{C}$ for 20 seconds, with the reduction of $1^{\circ} \mathrm{C}$ in the annealing temperature up to $60^{\circ} \mathrm{C}$, where more 25 cycles using this annealing temperature were performed. The final step was at $72^{\circ} \mathrm{C}$ for 5 minutes. The amplification products were resolved in $4 \%$ agarose gel electrophoresis at $100 \mathrm{~V}$ for 3 hours. The gel was treated with ethidium bromide $\left(0.5 \mathrm{mg} \cdot \mathrm{mL}^{-1}\right)$ and the image was processed under UV light by the Eagle Eye II system (Stratagene, La Jolla, CA).

\section{RESULTS AND DISCUSSION}

\section{Isoenzymatic pattern analyses}

The isoenzyme electrophoretic profile extracted from seeds showed, in general, a higher number of bands with larger size and intensity followed by isoenzymes extracted from leaves and coleoptiles, respectively. Only the bglucosidase enzyme (bGLU) did not show activity for any of the three tissues evaluated.

The glutamate-oxaloacetate transaminase (GOT) showed activity in seeds and leaves, revealing monomorphic patterns for both tissues. The phosphoglucomutase (PGM) and 6phosphoglucomate dehydrogenase (PGDH) were active only in seeds (Figure 1), without satisfactory resolution for genetic purity analysis. However, Goodman and Stuber (1987) found activity for those enzymatic systems in the whole maize plant. The possible explanation for low activity detected in this study could be due to the differences in gene expression among the developmental stages of the seedlings.

The enzyme alcohol dehydrogenase (ADH) showed activity only in the seeds, with monomorphic bands for all the genetic materials (Figure 1). For this enzyme, the expression of two loci during the first stage of seed development was identified, corroborating with the results from Torggler et al. (1995). Acid phosphatase (ACP) showed 

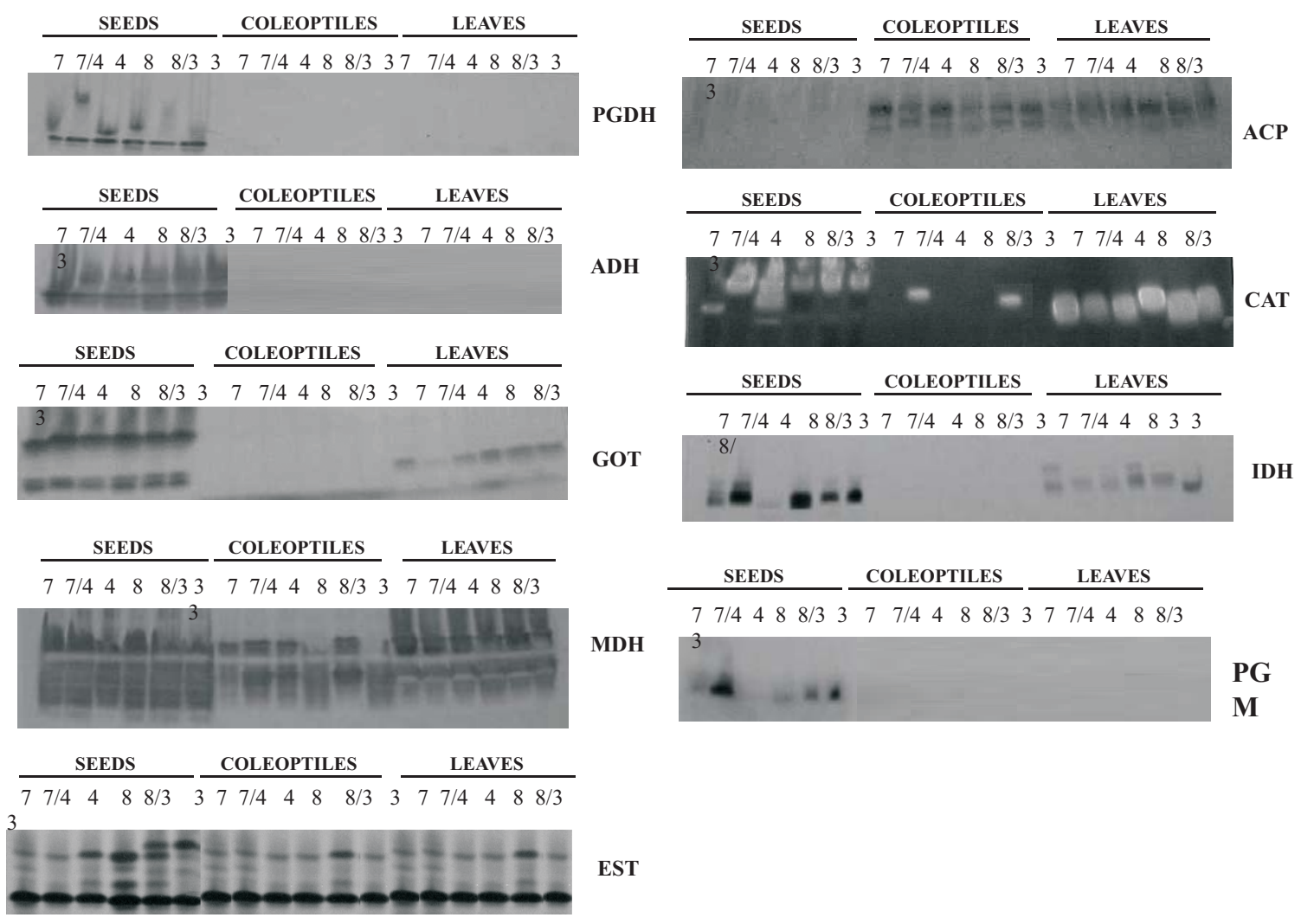

FIGURE 1. Enzymatic profiles of the 6 phosphoglucamate dehydrogenase (PGDH), acid phosphatase (ACP), alcohol dehydrogenase (ADH), catalase (CAT), glutamate-oxalacetate transaminase (GOT) isocitrate dehydrogenase (IDH), malate dehydrogenase (MDH), phosphoglucomutase (PGM) e esterase (EST), extracted from seeds, coleoptiles and leaves of two single-cross hybrids and their parental lines.

activity in the coleoptiles and leaf tissues, in agreement with Efron (1970), where the bands were monomorphic between all lines (Figure 1). The absence of acid phosphatase activity in the seed may have occurred due to the lack of microbiological and aging processes in the seeds. This enzyme is involved in ester hydrolysis that could act over the phospholipid membrane, as a consequence of the lipid peroxidation. Silva (1997) and Brandão Júnior (1996) showed that greater activity of acid phosphatase occurred when seeds were infected with microorganisms or when the seeds were submitted to an aging process, due to the increasing rate in the lipid peroxidation activities.

Among the isoenzymatic systems studied here, only esterase (EST), malate dehydrogenase (MDH) and catalase (CAT) showed activity in all tissues (seeds, coleoptiles and leaves). The electrophoretic profiles of malate dehydrogenase did not allow the differentiation between hybrids from their parents, in contradiction to the results from Bigen et al. (1995). The enzymatic patterns were different among the tissues
(Figure 1), probably due to the expression of different loci of the MDH in the seeds, coleoptiles and leaves, as already mentioned by Goodman and Stuber (1987).

Catalase was polymorphic in all tissues evaluated (Figure 1), whose profile in the coleoptiles allowed distinguishing the two single-cross hybrids from their respective female parental lines. However, the enzymatic pattern in the seeds differed only the hybrid UFLA $7 / 4$, while in leaves, only the hybrid UFLA $8 / 3$ could be discriminated from its parental lines. These results were different from the ones reported by HeidrichSobrinho (1982) who was unable to distinguish nine maize inbred lines with this system. The divergences in the results was probably related to the differences in the genetic materials. However, this enzymatic system has to be carefully applied in the cultivar differentiation, since Imolesi (1999) observed influence of nitrogen supply in this isoenzymetic pattern.

For the coleoptiles and leaves, esterase (EST) showed a monomorphic electrophoretic profile among the hybrids and their respective parents. The EST pattern in the seeds was 
monomorphic for UFLA 7/4, but showed a Mendelian segregation for the single-cross hybrid UFLA $8 / 3$ and its parental lines (Figure 1). This result is in agreement with the data from Yen (1987) that found polymorphism between the parental lines in a rice single-cross hybrid, reinforcing the applicability of this system in the evaluation genetic purity in seeds from different crops.

Isocitrate dehydrogenase (IDH) showed activity in seeds and leaves (Figure 1), in disagreement with the results obtained by Goodman and Stuber (1987), who reported enzymatic activity in all maize tissues. In the leaf tissues, the IDH electrophoretic profile was poorly resolved with a limited number of bands, and was not suitable for a trustworthy evaluation. However, its enzymatic pattern in seeds allowed the discrimination of both UFLA 7/4 hybrid parental lines. The same was not possible for UFLA $8 / 3$ hybrid, whose difference was only related to the thickness of the bands between the parents, causing doubts in the result interpretation.

The results from isocitrate dehydrogenase, catalase and glutamate-oxaloacetate transaminase gave a distinguished gene expression in the different tissues analysed. Meanwhile, although the coleoptiles show band patterns less modified in function in presence of microorganisms (Silva, 1997), in this study only the enzymatic catalase system showed difference in the hybrid electrophoretic profile and its respectively parents. In the seed analysis activity was observed in almost all systems that gave higher difference between the hybrids and their parents.

The enzymatic patterns of catalase, isocitrate dehydrogenase and esterase allowed the differentiation of both single-cross hybrids and their respective parental lines, in which the esterase pattern presented a Mendelian segregation for the UFLA $8 / 3$ hybrid, enabling a safer genetic purity certification. However, microorganism infection, physiological stages and environmental conditions may have a strong influence in the isoenzyme electrophoretic pattern (Brandão Júnior, 1996; Silva, 1997) that implies some restrictions to the wide use of this technique in the genetic purity analysis.

\section{SSR markers}

Three (11.1\%) of the 27 SSR did not segregate as a Mendelian markers in the $7 / 4$ hybrid and only one of such locus $(3.7 \%)$ in the $8 / 3$ hybrid. Non-Mendelian segregation of markers was also detected in 19\% of SSR primers evaluated in 13 hybrids and their progenitors by Smith et al. (1997). These distortions are frequently observed in SSR markers and may be a consequence of residual heterozygosity in the parental lines, genetic contamination, mutations in the primer annealing sites or mistakes during replication by the Taq DNA polymerase. In addition, the polymorphic primers that distinguished the parental lines from the hybrids were widely spread in the maize genome (Table 1), indicating a random distribution of the differences between the maize inbred lines.

The evaluation of a single seed is a very important step in the genetic purity analysis. However, the uses of whole seeds have been questioned as source of DNA, since around $80 \%$ of maize seed consists of the endosperm that has more contribuition from the female counterpart (3n) and could affect the allelic pattern in the hybrids. One possibility would be the utilization of only the embryo or vegetative tissue, whose cells are $2 \mathrm{n}$. In the first type of tissue, the amount of material to be analysed would be substantially reduced, while both tissues would require a longer period of time and a labor-intense methodology, increasing the costs of each analysis. Indeed, in order to overcome this problem, individual whole seeds and the leaves were used as source of DNA extraction. The amplification using the SSR primer bnlg2291 showed the same polymorphic pattern for both tissues (Figure 2), indicating that the high proportion of $3 \mathrm{n}$ tissue in the seed did not affected the SSR profile in the hybrids. This result reinforced considerations by McDonald et al. (1994), who highlighted the importance of DNA extraction from whole seeds as a strategy to enable the use of DNA markers as an efficient and

TABLE 1. SSR loci evaluated among the single-cross hybrids and the respective parental lines, including the position and primer sequences

\begin{tabular}{lccc}
\hline SSR locus & Position (Bin) & & \\
\hline Bnlg109 & 1.02 & mmc0241 & 6.05 \\
Bnlg381 & 2.03 & phi112 & 7.01 \\
Nc003 & 2.06 & umc1015 & $7.02-7.03$ \\
Mag1a01 & 2.08 & umc1016 & 7.02 \\
Bnlg420 & 3.05 & umc1036 & 7.02 \\
Mmc0071 & 3.05 & phi116 & 7.06 \\
Bnlg197 & 3.07 & phi115 & 8.03 \\
Umc1031 & 4.05 & bnlg1031 & 8.06 \\
Bnlg2291 & 4.07 & MAC.E01.C01 & 8.09 \\
Mmc0321 & 4.08 & umc1033 & 9.02 \\
Bnlg589 & 4.11 & bnlg1884 & 9.05 \\
Bnlg1208 & 5.03 & bnlg128 & 9.07 \\
Bnlg278 & $5.05-5.06$ & phi059 & 10.02 \\
Bnlg238 & 6.00 & & \\
\hline
\end{tabular}

${ }^{1} \mathrm{Bin}$ is the chromosome position defined by a set of core markers and named by the maize chromosome number, followed by decimal units representing the positions along each chromosome starting from the top of the short arm. 


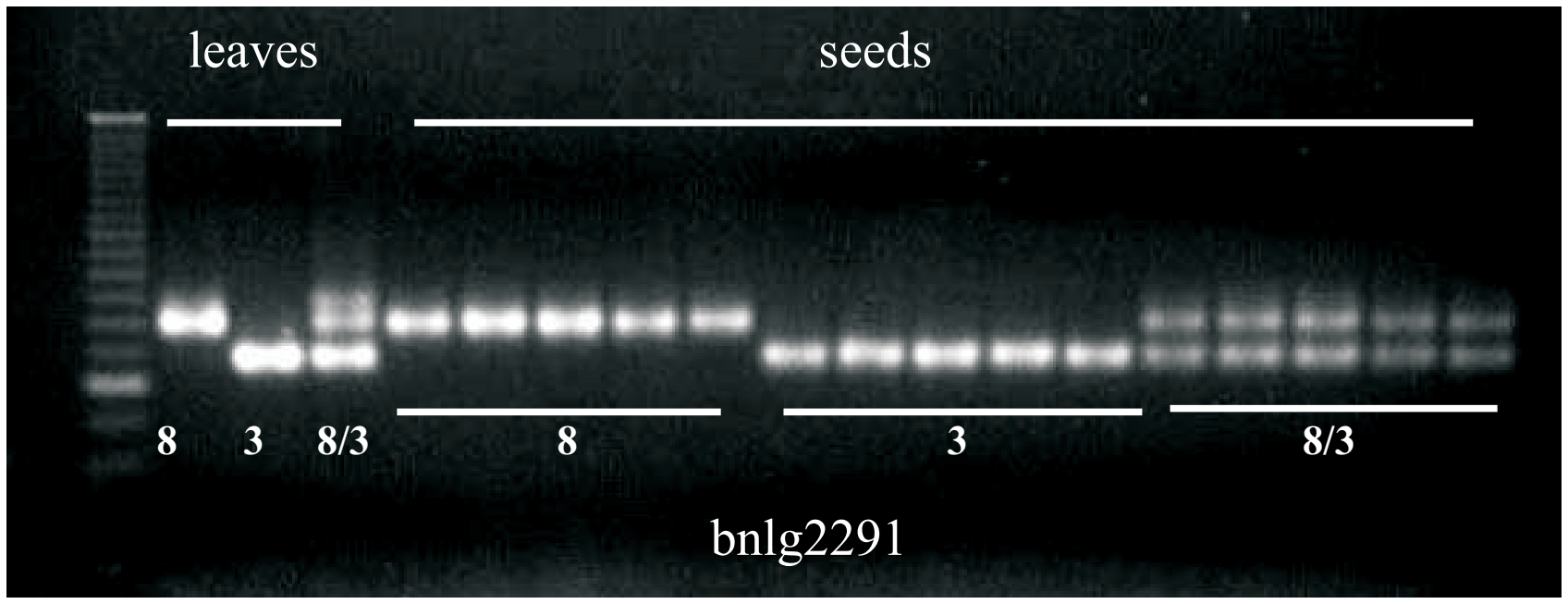

FIGURE 2. Amplification pattern of the SSR primer bnlg2291 using DNA extracted from leaves and seeds of the single-cross hybrid UFLA 8/3, its male (UFLA 8) and female (UFLA 3) inbred lines.

fast methodology for seed certification.

Besides the efficiency of morphological markers in maize genetic purity analysis (Salgado et al., 2001), some isoenzymatic systems were also shown to be good candidates to evaluate genetic contamination in seeds. However, the great availability of SSR primers for many species associated with all the advantages mentioned above and the possibility of extracting DNA from the whole seeds, could point to SSR markers as the great choice for genetic purity and cultivar protection analyses.

\section{CONCLUSIONS}

The enzymatic systems catalase and isocitrate dehydrogenase were able to distinguish the hybrids UFLA 8/ 3 and UFLA 7/4 from their parental line.

Esterase showed a Mendelian segregation pattern for UFLA 8/3 hybrid, that enabled a safer genetic purity certificate.

Microsatellites were able to differentiate between the hybrids and the respective parental lines as a fast, precise and environment free methodology and should be possible to use a seeds as source of DNA extraction, in order to accelerate and facilitate the whole process of genetic purity analysis.

\section{REFERENCES}

ALFENAS, A.C. Eletroforese de proteínas e isoenzimas. v.1 Viçosa: UFV, 1998. 242p.

ASSOCIATION OF OFFICIAL SEEDS ANALYSTS. Cultivar purity testing. Lansing:AOSA, 1991. 371p.

BILGEN, G., DOMIR, I., MARQUARD, R. Study on the identification of genetic constituition by means of isoenzyme electrophoresis in maize. Turkish Journal of Agriculture and Forestry, Ankara, v.19, n.2, p.95-102, 1995.

BRANDÃO JUNIOR, D.E. Eletroforese de proteína e isoenzima na avaliação da qualidade de sementes de milho. 1996.110f. Dissertação (Mestrado em Fitotecnia) - Universidade Federal de Lavras, Lavras, 1996.

COOKE, R.J. Gel electrophoresis for the identification of plant varieties. Journal of Chromatography, Amsterdam, v.698, n.1/2, p.281-299, 1995.

EFRON, Y. Tissue specific variation in the isozyme pattern of the AP acid phosphatase in maize. Genetics, Princeton, v.65, n.4 p.575-583, 1970 .

GOODMAN, M.M.; STUBER, C.W. Maize. In: TANKSLEY, S.D.; ORTON, T.J. (Ed.). Isozymes in Plant Genetics and Breeding. (Part B). Amsterdam: Elsevier, 1987.p.1-33.

GUIMARÃES, C.T.; MOREIRA, M.A. Genética Molecular Aplicada ao Melhoramento de Plantas. In: BORÉM, A. (Ed.) Melhoramento de Espécies Cultivadas. Viçosa: UFV, 1999. p.715740 .

HEIDRICH-SOBRINHO, E. Isoenzimas como marcadores genéticos na identificação de nove linhagens de milho. Pesquisa Agropecuária Brasileira, Brasília, v.17, n.2, p.281-286, 1982.

IMOLESI, A.S. Efeito da adubação nitrogenada na qualidade fisiológica, em características morfo-agronômicas e nos padrões eleroforéticos de proteínas e isoenzimas de sementes de milho. 1999. 57f. Dissertação (Mestrado em Fitotecnia) - Universidade Federal de Lavras, Lavras, 1999.

KOZHUKHOVA, N.E.; SIVOLAP, Y.U.M. Identification and Registration of Maize Genotypes with the Use of Molecular Markers. Russian Journal of Genetics, Moscow, v.40, n.1, p. 49- 
$55,2004$.

LANZA, M.B.; GUIMARÃES, C.T.; SCHUSTER, I. Aplicação de marcadores moleculares no melhoramento genético. Informe Agropecuário, Belo Horizonte, v.21, n.204, p.97-108, 2000.

MAURIA, S.; SINGH, N.N.; MUKHERJEE, A.K.; BATH, K.V Isozyme characterisation of Indian maize inbreds. Euphytica, Wagening, v.112, n.3, p.253-259, 2000.

MCDONALD, M.B.; ELLIOT, L.J.; SEEENEY, P.M. DNA extraciton from dry seeds for RAPD analyses in varietal identification studies. Seed Science and Technology, Zürich, v.22, n.1, p.171-176, 1994.

ORMAN, B.A.; LAWRANCE, G.D.; DOWNES, P.M.; PHILLIPS, D.S.; RIPBERGER, C.J. Assessment of maize inbred genetic purity by isoenzyme electrophoresis. Seed Science and Technology, Zürich, v.19, n.3, p.527-553, 1991.

SALGADO, K.C.C.; VIEIRA, M.G.G.C.; VON PINHO, E.V.R.; VON PINHO, R.G.; GUIMARÃES, C.T.; SOUSA, L.V. Certificação da pureza genética em sementes híbridas de milho por meio de marcadores morfológicos. Revista Brasileira de Sementes, Brasília, v.23, n. 1, p.232-238, 2001.
SILVA, E.A.A. Padrões eletroforéticos de isoenzimas e proteínas de sementes e coleoptilos de milho em associação com microrganismos. 1997. 87f. Dissertação (Mestrado em Fitotecnia) - Universidade Federal de Lavras, Lavras, 1997.

SMITH, J.S.C.; REGISTER III, J.C. Genetic purity and testing technologies for seed quality: a company perspective. Seed Science Research, Wallingford, v.8, n.2, p.285-293, 1998.

SMITH, J.S.C.; CHIN, E.C.L.; SHU, H.; SMITH O.S.; WALL S.J.; SENIOR M.L.; MITCHELL S.E.; KRESOVICH, S.; ZIEGLE, J. An evaluation of the utility of SSR loci as molecular markers in maize (Zea mays L.): comparisons with data from RFLPS and pedigree. Theoretical and Applied Genetics, Berlim, v.95, n.1/2, p.163-173, 1997.

TORGGLER, M.G.F.; CONTEL, E.P.B.; TORGGLER, S.P. Isoenzimas: variabilidade genética em plantas. Ribeirão Preto: Sociedade Brasileira de Genética, 1995. 186p.

YEN, C.C. Identification of the genuineness and the purity of hybrid rice (Oryza sativa ssp. Indica) and its parental lines by electrophoretic analysis of esterases. Seed Science and Technology, Zürich, v.15, n.3, p.645-649, 1987. 